\title{
$\nabla$ \\ Analysis of effectiveness of a surgical treatment algorithm for basal cell carcinoma*
}

\author{
Flávio Barbosa Luz ${ }^{1,2}$ \\ Gilberto Perez Cardoso ${ }^{1}$
}

Camila Ferron ${ }^{1}$

DOI: http://dx.doi.org/10.1590/abd1806-4841.20165919

\begin{abstract}
BACKGROUND: Surgical excision is the treatment of choice for basal cell carcinoma and micrographic surgery considered the gold standard, however not yet used routinely worldwide available, as in Brazil. Considering this, a previously developed treatment guideline, which the majority of tumors were treated by conventional technique (not micrographic) was tested .

Овјестіvе: To establish the recurrence rate of basal cell carcinomas treated according to this guideline.

Method: Between May 2001 and July 2012, 919 basal cell carcinoma lesions in 410 patients were treated according to the proposed guideline. Patients were followed-up and reviewed between September 2013 and February 2014 for clinical, dermatoscopic and histopathologic detection of possible recurrences.

Results: After application of exclusion criteria, 520 lesions were studied, with $88.3 \%$ primary and $11.7 \%$ recurrent tumors. Histological pattern was indolent in $85.5 \%, 48.6 \%$ were located in high risk areas and $70 \%$ small tumors. Only $7.3 \%$ were treated by Mohs micrographic surgery. The recurrence rate, in an average follow-up period of 4.37 years, was $1.3 \%$ for primary and $1.63 \%$ for recurrent tumors. Study limitations: unicenter study, with all patients operated on by the same surgeon.

ConcLusion: The treatment guideline utilized seems a helpful guide for surgical treatment of basal cell carcinoma, especially if micrographic surgery is not available.
\end{abstract}

Keywords: Mohs surgery; Carcinoma, basal cell; Treatment outcome; Recurrence

\section{INTRODUCTION}

Incidence of basal cell carcinoma (BCC) is increasing. In the USA, more than 3.5 million new cases of nonmelanoma skin cancer were estimated for 2014, and it was also noted that the number of women under 40 diagnosed with BCC more than doubled in the last 30 years. ${ }^{1}$

Although less than $50 \%$ of the Brazilian population is Caucasian, nonmelanoma skin cancer is also prevalent in Brazil, representing $25 \%$ of all malignant tumors. ${ }^{2}$ For 2014 it was estimated 182,130 new cases of nonmelanoma skin cancer, and BCC corresponded to $70 \%$ of these diagnoses. ${ }^{3}$

Surgical resection is the treatment of choice for BCC. ${ }^{4,5}$ Currently, in the USA, Mohs micrographic surgery (MMS) is indicated for all recurrent BCCs, except for superficial ones in low risk areas. For primary tumors, it is indicated for all aggressive tumors (except smaller than $0.5 \mathrm{~cm}$ in low risk areas); for all nodular tumors in high and moderate risk areas and for those larger than $2 \mathrm{~cm}$ in low risk areas; and for all superficial tumors in high risk areas and for those largest than $0.6 \mathrm{~cm}$ in moderate risk areas. ${ }^{6}$
An increase of $400 \%$ in the use of MMS in the US from 1995 to 2009 was reported, and one in four skin cancers are treated this way. ${ }^{6}$ In Brazil, MMS was introduced in the 1980's and, although widely accepted, its application is still limited, mainly due to the small number of specialized services. ${ }^{7,8}$

Because MMS is not yet widely and routinely used in many countries, the authors formulated in 2001 an algorithm to guide the surgical treatment of BCC, especially for places where there is still no broad access to micrographic techniques (Figures 1 and 2). ${ }^{9}$

The objective of this study was to evaluate the cure rate of BCCs patients treated surgically according to this algorithm. ${ }^{9}$ Although non-surgical techniques are accepted for some cases of BCCs, they were not covered in this study.

\section{METHODS}

Patients diagnosed with BCC treated in a private treatment center skin cancer were analyzed. The study involved patients treated between May 2001 and July 2012.

Received on 10.11.2015.

Approved by the Advisory Board and accepted for publication on 16.12.2015.

Study conducted at Centro de Cirurgia da Pele - Rio de Janeiro (RJ), Brazil.

Financial support: UFF Medical Science Masters Degree Scholarship (October 2013 to June 2014).

Conflict of interest: None.

Universidade Federal Fluminense (UFF) - Niterói (RJ), Brazil.

Private clinic - Rio de Janeiro (RJ), Brazil.

(C2016 by Anais Brasileiros de Dermatologia 
The study included: 1) lesions with histologic diagnosis of BCC treated surgically according to the proposed algorithm; and 2) patients who agreed to the proposed treatment. Exclusion criteria were: 1) patients with follow-up less than 6 months after treatment; 2) patients undergoing treatments other than surgery; 3 ) cases with no clinically visible lesion (previously treated by other doctors and referred to center after incomplete resection); 4) patients with Goltz-Gorlin syndrome; and 5) locally invasive lesions undergone palliative treatment (Figure 3).

The project was approved by the Ethics Review Board of the Universidade Federal Fluminense (document number: 155.435).

After initial classification of tumors in primary or recurrent, the pattern of histological growth was verified, according to previous biopsy. Presence of perineural invasion, metatypical sclerodermiform, infiltrative and micronodular subtypes were classified as aggressive growth; and nodular and superficial subtypes, as indolent growth, according to the Crowson classification. ${ }^{10}$

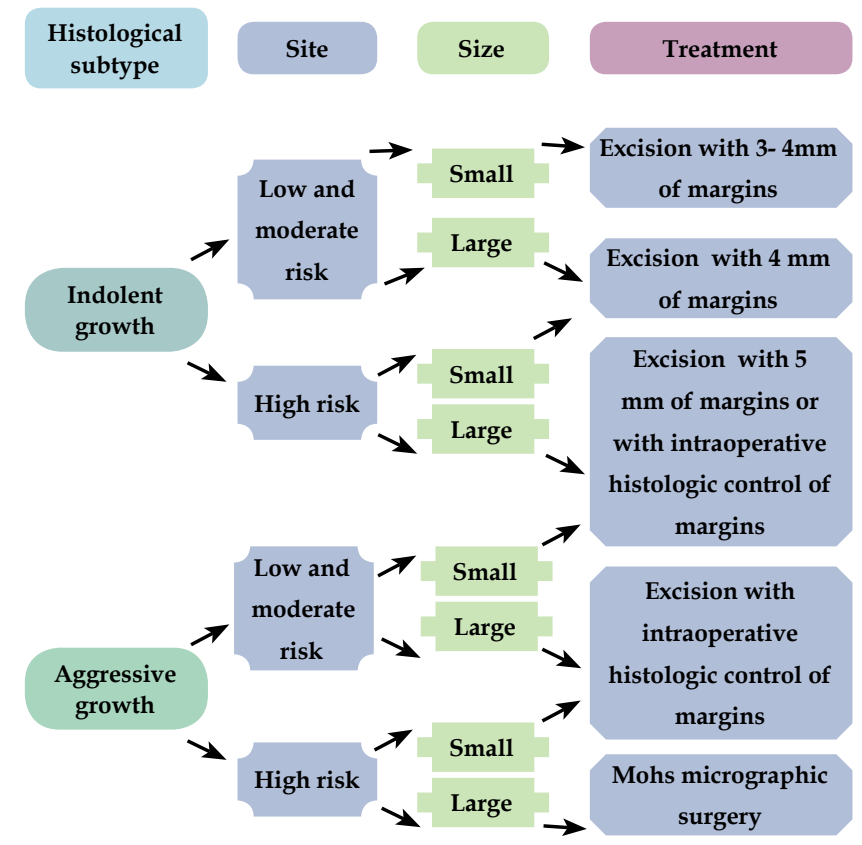

* superficial BCCs in low risk areas may be subject to non-surgical treatment

FIGURE 1: Algorithm for surgical treatment of primary BCC

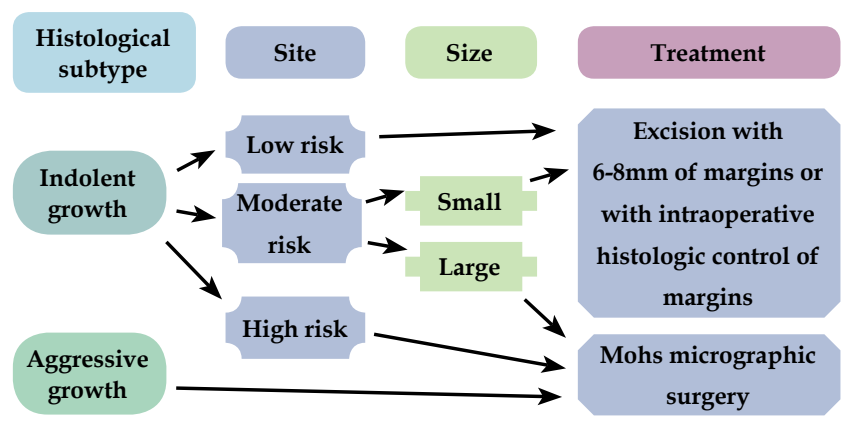

FIGURE 2: Algorithm for surgical treatment of recurrent BCC
Thereafter, the location of the tumor was classified as high, moderate or low risk, according to the Huang and Boyce classification. ${ }^{11}$

The tumor size classification takes into account its location. Thus, we considered large lesions those greater than $1 \mathrm{~cm}$, located in high risk areas, those greater than $2 \mathrm{~cm}$ in moderate risk areas and those greater than $4 \mathrm{~cm}$ located in low risk areas.

After this stratification, the tumors were treated according to the algorithm (Figures 1 and 2). Some primary BCCs, superficial, located in low risk areas, were treated by non-surgical methods. ${ }^{12}$

All patients were treated by the same surgeon (FBL).

The demarcation of tumor margins was made after clinical skin degreasing with 70\% alcohol, using surgical focus and maintaining the skin slightly stretched. From 2006, the polarized light dermoscopy (Dermalite II Pro®) started to be used to assist such delimitation.

In case of involvement of any of the margins in the histological analysis, new resections were made to confirm the total removal of the tumor.

From September 2013 to February 2014, patients were invited to attend the review consultation (with neutral observer), during which clinical signs and dermatoscopic relapse were sought. For patients who were unable to attend this consultation, telephone contact was made and data of the last visit made by the same surgeon were considered.

\section{RESULTS}

We evaluated 919 lesions in 410 patients. Of these, 301 met the exclusion criteria and 98 had incomplete registry data, preventing its inclusion. Thus, 521 lesions in 316 patients were effectively studied, 459 of these were primary tumors and 61 were recurrent tumors.

The general characteristics of the sample are shown in table 1 .

\section{Histologic subtype of tumors}

The nodular subtype was the most frequent, both in the group of primary and recurrent tumors $(64.8 \%$ and $40.9 \%$, respectively) (Table 2). When tumors were classified according to histologic growth pattern, the majority of primary and recurrent tumors were indolent $(87.9 \%$ and $59.1 \%$, respectively).

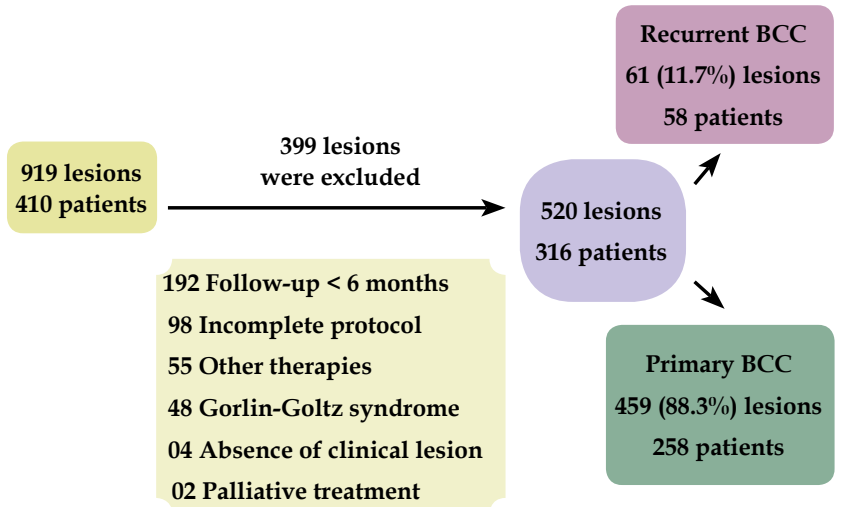




\section{Tumor site}

The vast majority of primary (63.6\%) and recurrent $(85.2 \%)$ tumors were located in the head and neck. In the group of primary tumors, trunk was the most frequent isolated place $(26.44 \%)$. In the group of recurrent, nose was the most commonly affected (36\%), followed by the forehead (16.4\%) (Table 3).

In relation to risk areas, $47.5 \%$ of primary tumors and $57.4 \%$ of recurrent were located in high risk areas.

TABLE 1: Characteristics of the sample

\begin{tabular}{|c|c|c|c|}
\hline & Total & Primary BCC & Recurrent BCC \\
\hline Nr. of lesions & 520 & $459(88.3 \%)$ & $61(11.7 \%)$ \\
\hline Nr. of patients & 316 & $258(81.6 \%)$ & $58(18.4 \%)$ \\
\hline \multicolumn{4}{|l|}{ Sex } \\
\hline Women & & $171(54.2 \%)$ & $139(53.8 \%)$ \\
\hline Men & & $145(45.8 \%)$ & $119(46.1 \%)$ \\
\hline Mean age & $\begin{array}{l}68.83 \text { years } \\
\text { (de } 30 \text { a } 98 \text { ) }\end{array}$ & 68.82 years & 67.77 years \\
\hline Women & & 70.16 years & 67.55 years \\
\hline Men & & 67.36 years & 68.25 years \\
\hline \multirow[t]{2}{*}{ Mean follow-up } & 4.37 years $( \pm 2.52)$ & 4.42 years & 3.98 years \\
\hline & $6 \mathrm{~m} / 12 \mathrm{y} 5 \mathrm{~m}$ & $6 \mathrm{~m} / 12 \mathrm{y} 5 \mathrm{~m}$ & $6 \mathrm{~m} / 10 \mathrm{y} 6 \mathrm{~m}$ \\
\hline \multicolumn{4}{|c|}{ Minimum/Maximum } \\
\hline$<5$ years & $331(63.6 \%)$ & $288(62.7 \%)$ & $44(72.1 \%)$ \\
\hline$\geq 5$ years & $189(36.4 \%)$ & $171(373 \%)$ & $17(27.9 \%)$ \\
\hline
\end{tabular}

TABLE 2: Histological subtype

\begin{tabular}{|c|c|c|c|c|}
\hline $\begin{array}{l}\text { Histological } \\
\text { subtype }\end{array}$ & $\begin{array}{l}\text { Primary } \\
\text { BCC }^{*} \\
\text { N: } 281\end{array}$ & $\begin{array}{l}\text { Recurrent } \\
\text { BCC }^{* *} \\
\mathrm{~N}: 44\end{array}$ & $\begin{array}{l}\text { Histological } \\
\text { subtype }\end{array}$ & $\begin{array}{l}\text { Primary } \\
\text { BCC* }^{*} \\
\text { N: } 281\end{array}$ \\
\hline Sclerodermiform & $10(3.5 \%)$ & $4(9.1 \%)$ & $\begin{array}{l}\text { Indolent } \\
\text { growth }\end{array}$ & $252(89.7 \%)$ \\
\hline Infiltrative & $3(1.1 \%)$ & $6(13.6 \%)$ & $\begin{array}{l}\text { Aggressive } \\
\text { growth }\end{array}$ & $29(10.3 \%)$ \\
\hline Metatypical & $1(0.3 \%)$ & $2(4.5 \%)$ & & \\
\hline Mixed & $15(5.3 \%)$ & $5(11.4 \%)$ & & \\
\hline Nodular & $182(64.8 \%)$ & $18(40.9 \%)$ & & \\
\hline Micronodular & - & $1(2.3 \%)$ & & \\
\hline Superficial & $63(22.5 \%)$ & $8(18.2 \%)$ & & \\
\hline Pigmented & $5(1.8 \%)$ & - & & \\
\hline Ulcerated & $2(0.7 \%)$ & - & & \\
\hline
\end{tabular}

\section{Tumor size}

Considering the tumor size, $88.6 \%$ of primary and $73.2 \%$ of recurrent tumors had maximum diameter of $2 \mathrm{~cm}$ (Table 4 ).

Most primary $(76 \%)$ and almost a third $(29.3 \%)$ of recurrent tumors were small according to their location.

\section{Treatment}

The vast majority of primary and recurrent tumors were treated by conventional surgery (CS) $(94.5 \%$ and $75.4 \%$, respectively), with $62 \%$ of primary and $74 \%$ of recurrent tumors subjected to intraoperative histological analysis of their margins (Table 5).

The rate of incomplete excision, among tumors treated by conventional surgery with intraoperative histological analysis of margins, was $4.1 \%$ (18 lesions) for primary and 4.3\% (two lesions) for recurrent tumors. Among primary tumors, the lateral margin was involved in 13 cases, the deep margin in two, and both margins, lateral and deep, in three cases. Among the recurrent tumors, one case presented lateral margin and the other presented deep margin affected. All were called for subsequent surgery and all underwent

TABLE 4: Tumor size

\begin{tabular}{lll}
\hline Size & $\begin{array}{l}\text { Primary BCC* } \\
\text { N: } \mathbf{2 8 0}\end{array}$ & $\begin{array}{l}\text { Recurrent BCC** } \\
\text { N: } \mathbf{4 1}\end{array}$ \\
\hline$\leq 2 \mathrm{~cm}$ & $248(88.6 \%)$ & $30(73.2 \%)$ \\
$>2 \mathrm{~cm}$ & $32(11.4 \%)$ & $11(26.8 \%)$ \\
Small & $213(76 \%)$ & $12(29.3 \%)$ \\
Large & $67(24 \%)$ & $29(70.7 \%)$ \\
\hline \multirow{2}{*}{ Not reported: 179} & $* *$ Not reported: 20 & \\
& & \\
& TABLE 5: Treatment &
\end{tabular}

\begin{tabular}{lll}
\hline $\begin{array}{l}\text { Treatment } \\
\text { Conventional surgery }\end{array}$ & $\begin{array}{l}\text { Primary BCC* } \\
94.5 \%(434)^{*}\end{array}$ & $\begin{array}{l}\text { Recurrent BCC** } \\
75.4 \%(46)^{* *}\end{array}$ \\
\hline $\begin{array}{l}\text { Postoperative histological } \\
\text { analysis of margins (paraffin) }\end{array}$ & $25.8 \%(112)$ & $13 \%(6)$ \\
$\begin{array}{l}\text { Postoperative histological } \\
\text { analysis of margins (frozen } \\
\text { section) }\end{array}$ & $62 \%(269)$ & $74 \%(34)$ \\
Mohs micrographic & $5.5 \%(25)$ & $24.6 \%(15)$ \\
\hline
\end{tabular}

* Not reported: $53 \quad$ ** Not reported: 6

TABLE 3: Tumor site

\begin{tabular}{|c|c|c|c|c|c|}
\hline Site & Primary BCC & Recurrent BCC & Site & Primary BCC & Recurrent BCC \\
\hline Nose & $100(21.8 \%)$ & $22(36 \%)$ & High risk & $218(47.5 \%)$ & $35(57.4 \%)$ \\
\hline Perioral & $40(8.7 \%)$ & $2(3.3 \%)$ & & & \\
\hline Temporal & $27(5.9 \%)$ & $1(1.7 \%)$ & & & \\
\hline Periocular & $26(5.6 \%)$ & $2(3.3 \%)$ & & & \\
\hline Ears and periauricular & $22(4.8 \%)$ & $8(13.1 \%)$ & & & \\
\hline Jaw $5(1.1 \%)$ & $1(1.6 \%)$ & & & & \\
\hline Forehead & $32(7 \%)$ & $10(16.4 \%)$ & Moderate risk & $77(16.8 \%)$ & $19(29.5 \%)$ \\
\hline Scalp & $5(1.1 \%)$ & $2(3.3 \%)$ & & & \\
\hline Cheek & $24(5.2 \%)$ & $4(6.5 \%)$ & & & \\
\hline Neck & $11(2.4 \%)$ & 0 & & & \\
\hline Upper limbs & $14(3 \%)$ & $2(3.3 \%)$ & Low risk & $164(35.7 \%)$ & $8(13.1 \%)$ \\
\hline Lower limbs & $32(7 \%)$ & $2(3.3 \%)$ & & & \\
\hline Trunk & $121(26.4 \%)$ & $5(8.2 \%)$ & & & \\
\hline
\end{tabular}


additional resection until confirmation of complete tumor excision.

Among the 466 tumors with available information, the surgical repair occurred in $56.9 \%$ (265) for simple flap; $19.5 \%$ (91) by direct closure; $14 \%$ (65) by complex flap; $8.5 \%$ (40) graft; and $1 \%$ (5) by second intention.

\section{Follow-up and recurrence of the algorithm}

The mean follow-up was 4.37 years (minimum 6 months and maximum 12 years and 5 months), with a mean of 4.42 years among primary tumors and 3.98 years among recurrent tumors.

The review consultation was performed with $21.7 \%$ (113) patients by a neutral observer; $51 \%$ (265) by the same surgeon; and via telephone contact by neutral observer in $27.3 \%$ (142) of the cases. In the latter group, $28.2 \%$ (40) of the cases mentioned follow-up by another doctor (Figure 4).

The overall relapse rate was $1.34 \%, 1.3 \%$ (6) between primary and $1.63 \%$ (1) between recurrent tumors.

In two of the cases of recurrence, the lesions were located in the nose, and in two others, the lesions were clinically nodular (Table 6).

Most recurrences occurred in the nose and in tumors clinically classified as nodular.
With the exception of lesion 3, which has not yet been re-operated, other cases were reoperated according to the recurrent tumors algorithm and, so far, they didn't present a new relapse (Table 6 and Figure 2).

\section{DISCUSSION}

The discreet prevalence in women in this study was similar to previous reports, although high prevalence in men has also has been reported. ${ }^{13-16}$ Mean age was 65 years (minimum of 30 and maximum of 98 years) and was similar to previous reports..$^{13,15,16}$

Similar to other reports, the nodular histologic subtype was the most frequent. There are reports showing the nose as the most affected site, but in this study, the trunk was the most common site among primary tumors $(26.4 \%)$, followed by the nose $(21.8 \%)$, which was the most frequent among the recurrent tumors $(36 \%){ }^{14,17,18,19}$ Similar to other studies, approximately half of the primary and recurrent tumors were small ( $54 \%$ and $49.2 \%$, respectively). ${ }^{13,18}$

Analyzing the cases according to the criteria adopted and tested in the algorithm (histologic growth pattern, risk areas and size according to location), $10.3 \%$ of primary tumors and $40.9 \%$ of recurrent tumors were aggressive; $47.5 \%$ of primary and $57.4 \%$ of re-

FIGURE 4: Characteristics of the sample according to the reviewer

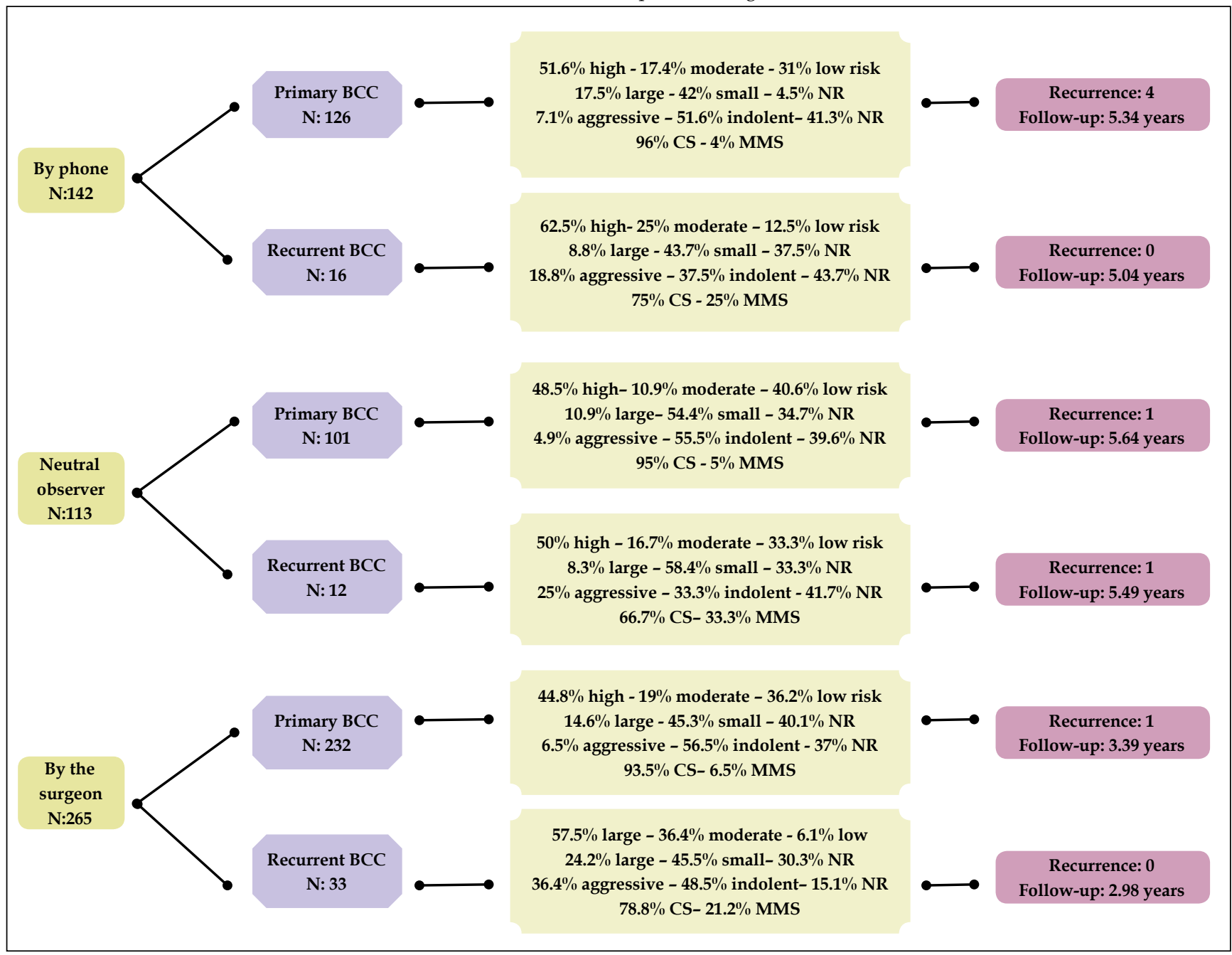

CS: conventional surgery; MMS: Mohs micrographic surgery; NR: not reported 
TABLE 6: Characteristics of the cases of recurrence treated according to the algorithm

\begin{tabular}{llllll}
\hline Patient & Tumor status & Histological/clinical types & Site & Size & Treatment \\
\hline 1 & Primary & Nodular/Nodular & Scalp & Small & CS with frozen section- 4mm margins \\
2 & Primary & Sclerodermiform / Nodular & Nose & Large & CS with frozen section - 5mm margins \\
3 & Recurrent & NR/NR & Nose & NR & MMS \\
4 & Primary & NR/Nodular & Nose & Large & CS with frozen section $-4 m m$ margins \\
5 & Primary & NR/Nodular & Nose & NR & MMS \\
6 & Primary & NR/ Sclerodermiform & Nose & Small & CS with frozen section $-3 m m$ margins \\
7 & Primary & Nodular/Nodular & Temporal & Small & CS with frozen section $-3 m m$ margins \\
\hline
\end{tabular}

CS: conventional surgery; NR: not reported; MMS: Mohs micrographic surgery

current tumors were located in high risk areas; and $24 \%$ of primary and $70.7 \%$ of the recurrent tumors were large.

Only $5.5 \%$ of primary and $24.6 \%$ of recurrent tumors were treated by MMS. If we applied the US indications of MMS ${ }^{6}$ to our sample, instead of the proposed algorithm, more than $70 \%$ of the treated cases would have indication for MMS.

More than half ( $63.1 \%$ - 303 of 480$)$ of tumors treated by conventional surgery underwent intraoperative histological analysis of margins, and incomplete excision rate was $4.1 \%$ (20 of 480). Bariani et al. ${ }^{14}$ obtained $8 \%$ of positive margins, excising well defined BCCs, smaller than $20 \mathrm{~mm}$, with surgical margins of $3 \mathrm{~mm}$, and poorly defined BCCs, larger than $20 \mathrm{~mm}$, with $5 \mathrm{~mm}$ margins. Nagore et al. obtained $24 \%$ of positive margins excising BCCs with margins of 2 to $3 \mathrm{~mm} .{ }^{20}$ Sherry et al. obtained incomplete excision rate of $3.2 \%$ excising primary BCCs with minimum margins of $3 \mathrm{~mm} .{ }^{16}$ Pichardo-Velazquez et al. obtained incomplete excision rate of $28.5 \%$, excising high risk BCCs with surgical margins of $5 \mathrm{~mm} .{ }^{21}$

The mean follow-up was 4.37 years $(36.3 \%$ of the lesions were followed for more than 5 years), which is close to what is considered ideal by Gulleth et al..$^{22}$

The overall recurrence rate of this study was $1.34 \% ; 1.30 \%$ among primary tumors and $1.64 \%$ among recurrent tumors. Among the six cases of recurrence, which occurred in primary tumors, five were treated by conventional surgery, with complete removal of the tumor confirmed by the intraoperative histological analysis of margins, and one was treated by MMS. The only tumor that recurred in the group of previously treated lesions was located in high risk area and treated by MMS.

Although Fleischer et al. claim that the surgeon's experience does not affect the probability of incomplete resection, as all lesions were treated by the same surgeon, it would be interesting that the algorithm was tested in other centers. ${ }^{23}$

There are reports of recurrence in 5 years of $1 \%$ for primary BCCs treated by MMS and of $10.1 \%$ for those treated by conventional surgery; and of $5.6 \%$ for recurrent tumors treated by MMS and of $17.4 \%$ the ones treated by conventional surgery. ${ }^{24}$ Mosterd et al., in a prospective randomized study, obtained recurrence of $4.1 \%$ for primary BCCs treated by conventional surgery and of $2.5 \%$ for those treated by MMS, in a mean follow-up of 5 years. ${ }^{25}$ For recurrent tumors, they obtained recurrence of $12.1 \%$ for conventional surgery and of $2.4 \%$ for MMS. Cigma et al., excising BCCs with margins between 3 and $10 \mathrm{~mm}$, according to their location, obtained recurrence of $2.6 \% .{ }^{26}$ Wetzig et al. reported recurrence in 5 years of $0.5 \%$ for primary BCCs and of $2.9 \%$ for the excised recurrent BCCs with histologic control in paraffin. ${ }^{18}$ Rowe et al. reported recurrence in 5 years of $1 \%$ for primary BCCs and of $5.6 \%$ for recurrent tumors treated by micrographic techniques. ${ }^{27,28}$ Some studies involving periocular BCCs, excised with intraoperative histological analysis of margins, reported relapse of $2.15 \%$ and $9.7 \%$ for primary tumors and of $4.4 \%$ and $14.2 \%$ for recurrent tumors. ${ }^{29-31}$

Although the results of this study are similar to those obtained with MMS, we do not consider the sacrifice of healthy skin that, although not tested, is greater than with micrographic techniques. This observation has been demonstrated by Muller et al. that, in a randomized study, obtained a mean surgical defect of 111.6 $\mathrm{mm}^{2}$ for small nodular BCCs treated by MMS versus $187.7 \mathrm{~mm}^{2}$ for conventional surgery. ${ }^{32}$

Among the excluded cases, there was a recurrence in a patient with Gorlin-Goltz syndrome, treated by conventional surgery, one in a patient submitted to MMS for palliation and one in a patient treated by photodynamic therapy.

\section{CONCLUSION}

Complete excision is the key to surgical treatment of BCC. Accordingly, MMS has its indications well established in the literature and is the treatment of choice for most cases. However, considering the cure rate obtained in these studies, to sites where MMS is not yet widely available, the proposed algorithm can be a useful guide to direct the surgical treatment of basal cell carcinoma.] 


\section{REFERENCES}

1. Christenson LJ, Borrowman TA, Vachon CM, Tollefson MM, Otley CC, Weaver AL, et al. Incidence of basal cell and squamous cell carcinomas in a population younger than 40 years. JAMA. 2005;294:681-90.

2. Brasil. Ministério do Planejamento, Orçamento e Gestão. Instituto Brasileiro de Geografia e Estatística. Censo Demográfico 2010. Características Gerais da População, Religião e Pessoas com Deficiência. Rio de Janeiro: IBGE; 2010.

3. Brasil. Ministério da Saúde. Instituto Nacional de Câncer José Alencar Gomes da Silva. Coordenação de Prevenção e Vigilância. Estimativa 2014: Incidência de Câncer no Brasil. Rio de Janeiro: Inca; 2014.

4. Telfer NR, Colver GB, Morton CA; British Association of Dermatologists. Line of actions for the management of basal cell carcinoma. Br J Dermatol. 2008;159:3548.

5. Gulleth Y, Goldberg N, Silverman RP, Gastman BR. What is the Best Surgical Margin for a Basal Cell Carcinoma: A Meta-analysis of the Literature. Plast Reconstr Surg. 2010;126:1222-31.

6. American Academy of Dermatology; American College of Mohs Surgery; American Society for Dermatologic Surgery Association; American Society forMohs Surgery; Ad Hoc Task Force, Connolly SM, et al. AAD/ACMS/ASDSA/ ASMS2012 Appropriate use criteria for Mohs Micrographic Surgery: A report of the American Academy of Dermatology, American College of Mohs Surgery, American Society for Dermatologic Surgery Association, and the American Society for Mohs Surgery. Dermatol Surg. 2012;38:1582-603.

7. Kopke LFF, Schmidt SV. Carcinoma basocelular. An Bras Dermatol. 2002;17:24982

8. Cernea S. Remoção dos Carcinomas Basocelulares. Considerações para a escolha do método terapêutico. J Soc Bras Cir Dermatol. 2001;29:8

9. Luz FB, Ferron C, Cardoso GP. Surgical treatment of basal cell carcinoma: an algorithm based on literature. An Bras Dermatol. 2015;90:377-83.

10. Crowson AN. Basal cell carcinoma: biology, morphology and clinical implications. Mod Pathol. 2006;19:S127-47.

11. Huang CC, Boyce SM. Surgical Margins of excision for basal cell carcinoma and squamous cell carcinoma. Semin Cutan Med Surg. 2004;23:167-73.

12. Aguayo-Leiva IR, Rios-Buceta L, Jaen-Olasolo P. Tratamiento quirúrgico vs no quirúrgico em el carcinoma basocelular. Actas Dermosifiliogr. 2012;101:683-92

13. Thomas DJ, King AR, Peat BG. Excision margins for nonmelanotic skin cancer. Plast Reconstr Surg. 2003;112:57-63.

14. Bariani RL, Nahas FX, Barbosa MV, Farah AB, Ferreira LM. Basal cell carcinoma: an updated epidemiological and therapeutically profile of an urban population. Acta Cir Bras. 2006;21:66-73.

15. Kyrgidis A1, Vahtsevanos K, Tzellos TG, Xirou P, Kitikidou K, Antoniades K, et al. Clinical histological and demographic predictors for recurrence and second primary tumours of head and neck basal cell carcinoma. A 1062 patient-cohort study from a tertiary cancer referral hospital. Eur J Dermatol. 2010;20:276-82.

16. Sherry KR, Reid LA, Wilmshurst AD. A five-year review of basal cell carcinoma excisions. J Plast Reconstr Aesthet Surg. 2010;63:1485-9.

17. Chinem VP, Miot HA. Epidemiologia do carcinoma basocelular. An Bras Dermatol 2011;86:292-305.

18. Wetzig T, Woitek M, Eichhorn K, Simon JC, Paasch U. Surgical excision of basal cell carcinoma with complete margin control: outcome at 5-year follow-up. Dermatology. 2010;220 :363-9.

19. Bisson MA, Dunkin CS, Suvarna SK, Griffiths RW. Do plastic surgeons resect basal cell carcinoma too widely? A prospective study comparing surgical and histological margins. Br J Plast Surg. 2002;55:293-7.

20. Nagore E, Grau C, Molinero J, Fortea JM. Positive margins in basal cell carcinoma: relationship to clinical features and recurrence risk. A retrospective study of 248 patients. J Eur Acad Dermatol Venereol. 2003;17:167-70.

21. Pichardo-Velázquez P, Domínguez-Cherit J, Vega-Memije Ma, Moreno-Coutiño $G$, Proy $H$. Surgical option for nonmelanoma skin cancer. Int J Dermatol. 2004;43:148-50.

22. Gulleth Y, Goldberg N, Silverman RP, Gastman BR. What is the Best Surgical Margin for a Basal Cell Carcinoma: A MetaAnalysis of the Literature. Plast Reconstr Surg. 2010;126:1222-31.

23. Fleischer AB Jr, Feldman SR, Barlow JO, Zheng B, Hahn HB, Chuang TY, et al. The specialty of the treating physician affects the likelihood of tumor-free resection margins for basal cell carcinoma: results from a multi-institutional retrospective study. J Am Acad Dermatol. 2001;44:224-30.
24. Batra RS, Kelley LC. Predictors of extensive subclincal spread in nonmelanoma skin cancer treated with Mohs Micrographic Surgery. Arch Dermatol. 2002;138:1043-51.

25. Mosterd K, Krekels GA, Nieman FH, Ostertag JU, Essers BA, Dirksen CD, et al. Surgical excision versus Mohs' micrographic surgery for primary and recurrent basal-cell carcinoma of the face: a prospective randomized controlled trial with 5-year follow-up. Lancet Oncol. 2008;9:1149-56.

26. Cigna E, Tarallo M, Maruccia M, Sorvillo V, Pollastrini A, Scuderi N. Basal cell carcinoma: 10 years of experience. J Skin Cancer. 2011;2011:476362.

27. Rowe DE, Carroll RJ, Day CL Jr. Long-term recurrence rates in previously untreated (primary) basal cell carcinoma: implications for patient follow-up. $J$ Dermatol Surg Oncol. 1989:15:315-28.

28. Rowe DE, Carroll RJ, Day CL Jr. Mohs' surgery is the treatment of choice for recurrent (previously treated) basal cell carcinoma. J Dermatol Surg Oncol. 1989;15:424-31.

29. Khandwala MA, Lalchan SA, Chang BY, Habib M, Chakrabarty A, Cassells-Brown A. Outcome of periocular basal cell carcinoma managed by overnight paraffin section. Orbit. 2005;24:243-7.

30. Conway RM, Themel S, Holbach LM. Surgery for primary basal cell carcinoma including the eyelid margins with intraoperative frozen section control: comparative interventional study with a minimum clinical follow up of 5 years. Br J Ophthalmol. 2004;88:236-8.

31. Wong VA, Marshall JA, Whitehead KJ, Williamson RM, Sullivan TJ. Management of periocular basal cell carcinoma with modified en frozen section controlled excision. Ophthal Plast Reconstr Surg. 2002:18:430-5.

32. Muller FM, Dawe RS, Moseley H, Fleming CJ. Randomized comparison of Mohs micrographic surgery and surgical excision for small nodular basal cell carcinoma: tissue-sparing outcome. Dermatol Surg. 2009;35:1349-54.
MAILING ADDRESS:
Flávio Barbosa Luz
R. Guapiara, 78 - Tijuca
20521-180 - Rio de Janeiro - RJ
Brazil
Email:flavio@cirurgiadapele.com

How to cite this article: Luz FB, Ferron C, Cardoso GP. Analysis of effectiveness of a surgical treatment algorithm for basal cell carcinoma. An Bras Dermatol. 2016;91(6):726-31. 